\title{
Indonesia and the Aircraft Lease Implementation in Its Airlines Amid Covid-19 Pandemic: A Perspective from Investment Law
}

\author{
Anastasia Arina Sucirosari Tarigan ${ }^{1 *}$, An-an Chandrawulan ${ }^{2}$, Prita Amalia ${ }^{3}$ \\ 1. Department of Transnational Business Law, Faculty of Law, Universitas Padjadjaran, Jatinangor, Kabupaten \\ Sumedang, Jawa Barat 45363, Indonesia \\ 2. Department of Transnational Business Law, Faculty of Law, Universitas Padjadjaran, Jatinangor, Kabupaten \\ Sumedang, Jawa Barat 45363, Indonesia \\ 3. Department of Transnational Business Law, Faculty of Law, Universitas Padjadjaran, Jatinangor, Kabupaten \\ Sumedang, Jawa Barat 45363, Indonesia
}

\begin{abstract}
As a country where the majority of its airline fleets are obtained through the practice of aircraft lease with foreign companies, Indonesia acts as the host state for lessors who provide leases for its national airlines. The unstable condition of airlines during the Covid-19 pandemic has resulted in the inability of airlines to pay the aircraft lease costs, thus causing problems with lessors as the foreign parties who entrust their assets to airlines as the operators of leased aircraft. Based on the investment law, it is the obligation of Indonesia as the host state to ensure that the lessor as the investor gets the protection and fulfilment of their rights. This research is intended to see the extent of the Indonesian Government's role in the aircraft lease activities during the Covid-19 pandemic situation. This study uses the normative juridical research method, by linking it to the phenomenon in the implementation of aircraft leases during the pandemic. The results of the study indicate that there is not any specific rule or policy issued by the Government which is intended for the implementation of aircraft lease by Indonesian airlines during this pandemic situation, yet.
\end{abstract}

Keywords: aircraft lease, pandemic, investment, and airlines.

DOI: $10.7176 / \mathrm{JLPG} / 112-14$

Publication date:August $31^{\text {st }} 2021$

\section{Introduction}

The aviation industry has been one of the sectors that heavily affected by the Covid-19 pandemic since early 2020. The Covid-19 pandemic has caused a decrease in the number of air transportation passengers due to the implementation of the travel ban and travel restrictions, which in turn has an impact on the huge losses experienced by airlines from 2020 to 2021 this time.

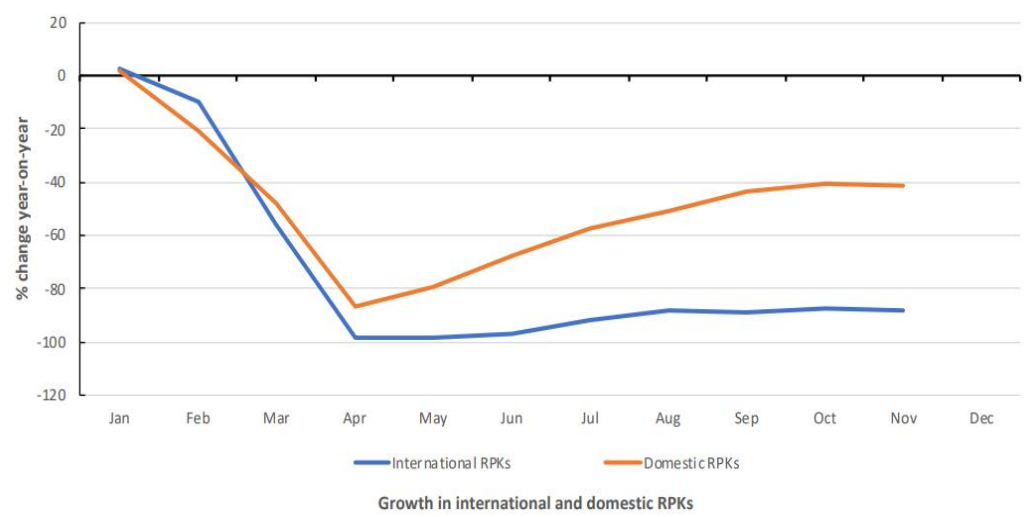

Figure 1. Air Travel Demand 2020

Source: IATA Air Passenger Monthly Analysis (KPMG, 2021)

As one of the fields that is considered effective and easy to generate profits and large free cash flow, the aviation industry is one of the areas of investment that is in great demand by investors, both domestic and foreign investors (Etfs, 2017). The obstacles that arise from the Covid-19 pandemic on airlines as one of the providers of transportation services, resulting in the emergence of economic losses experienced by airlines, and also have an impact on the investments activity in that industry. The United Nations Conference on Trade and Development (UNCTAD) stated that one of the investment sectors that is most affected by the Covid-19 pandemic is investments in airlines. Revenue from airlines decreased by $42 \%$ and became the second industry with the hardest hit in terms of investment during this pandemic situation (UNCTAD, 2020). 
Table 1. Industries with the Hardest Downward on FDI Activity in 2020

\begin{tabular}{|c|c|}
\hline Industry & Downward Percentage \\
\hline Automotive & $-44 \%$ \\
\hline Airlines & $-42 \%$ \\
\hline Energy and Basic Materials & $-13 \%$ \\
\hline
\end{tabular}

Source: United Nations Conference on Trade and Development (UNCTAD, 2020)

The Covid-19 pandemic has caused approximately $\geq 80 \%$ of global transportation fleets to be temporarily grounded in March 2020, resulting in airline shares cutting by $50 \%$, from levels before the pandemic was declared a crisis (Jia, 2020). In addition to losses in investment in the form of shares, investment in the aviation sector which is also heavily affected during this pandemic is aircraft lease, as the practice of foreign direct investment (FDI).

Aircraft leases have so far been a form of investment in the aviation industry that chosen by many investors because the cash flows are more stable and planned, and the income received by the lessor is fixed and certain over a long period of time (Capital Aviation, n.d.), these are made investing with aircraft lease is considered profitable. Not only is it a good investment for the lessor, but aircraft leasing is also a profitable option for the airline because it allows airlines to deal with short and medium-term demand fluctuations, without having to make capital-intensive investments (KGAL Real Investments, 2016).

Two major Indonesian airlines, namely Garuda Indonesia Group and Lion Air Group, are using aircraft that are mostly obtained by lease. Until 2020, the Garuda Indonesia Group (which includes Citilink), has a total of 20 aircraft units, and 190 leased aircraft units. During 2020 Garuda Indonesia Group suffered a loss of 54.4\% yearon-year (YoY) or equals to 6.89 million passengers from early January 2020 to July 2020 (Parama, 2020). Meanwhile, Indonesia's largest private airline, Lion Air Group, owns a total of 44 aircraft units and leases 112 aircraft units from a total of 50 leasing companies (CH-Aviation, 2021).

As the lessees in the practice of aircraft lease, both Garuda Indonesia and Lion Air have faced difficulties in meeting payments for their aircraft leases during this pandemic. Garuda Indonesia (GIAA) is reportedly in negotiations with one of the companies where he leased the aircraft, namely Nordic Aviation Capital (NAC), which is a leasing company domiciled in Denmark. Garuda Indonesia wants to return 12 (twelve) Bombardier CRJ-1000 aircraft to NAC, because these planes have not been flown since February 1, 2021, even though the Bombardier aircraft rental contract is still valid until 2027. The return of 12 Bombardier aircraft is based on losses caused by the inoperability of the planes due to the Covid-19 pandemic. The total loss is US\$57 million per year, of which US\$30 million is aircraft operating costs per year, and US\$27 million is aircraft rental costs per year. Regarding this matter, Garuda Indonesia negotiated with NAC, to discuss part of the contract which states that even though Garuda terminates the contract before the contract expires, Garuda Indonesia still needs to pay the agreed costs until the contract period ends. This part was about to be negotiated by Garuda with NAC to reduce costs. Not only with NAC, but Garuda Indonesia is also negotiating with Export Development Canada (EDC), to return 6 (six) Bombardier aircraft of the same type, namely the CRJ-1000, which they leased from that company (Wareza, 2021).

Meanwhile, in September 2020, Lion Air Group was sued by a leasing company, named Goshawk Aviation Ltd (Ireland), in a court in London, England, because Lion Air Group was deemed not to have fulfilled its obligations in the lease agreement. It is said that Lion Air Group has arrears worth 1.6 million to 2.5 million Pound Sterling on Goshawk. The thing that is also part of the dispute is about a section in the lease agreement between Lion Air Group and Goshawk which stated that Lion Air agreed to provide a deposit (down payment) of 5.5 million Pound Sterling (The Insider Stories, 2020). In the same case with Garuda Indonesia, the problem between Lion Air Group and Goshawk Aviation Ltd as its leasing company arose because of the number of aircraft that could not be operated due to the reduced of flights and passenger capacity during the Covid-19 pandemic. This then has a major impact on the income received by airlines, and then on the inability of airlines to make payments to their leasing companies. As a result of this pandemic, losses are not only experienced by airlines, but also by leasing companies as the lessors who invest in airlines.

The difficult conditions caused by the Covid-19 pandemic have caused complicated problems for airlines and other parties related to them, including the lessor in the implementation of aircraft leases. From this situation, there is a need which arises from both lessors (the leasing company) and lessee (the airlines), to ensure and guarantee that their relationship that based on the lease agreement can still be carried out, and the rights and obligations in it will still be fulfilled. As the host state, the lessee's state can use their "Right to Regulate" to manage activities of the aviation industry, including aircraft leases, during this pandemic. This "Right to Regulate" can be a solution for lessees and lessors but on the other side, can also be an intervention that 
interferes the implementation of aircraft lease. This paper will discuss the actions and regulations issued by the Government of Indonesia as the host state, in efforts to protect the implementation of aircraft leases during the Covid-19 pandemic.

\section{Host State Responsibilities in the Implementation of Aircraft Leasing}

\section{1. The Role of Host State in the Implementation of Foreign Investment}

Foreign investment activities usually occur between 2 (two) parties, which are the host state, and the foreign investors from the home state. A host state is a country that accepts foreign investors to invest in its country or is briefly referred to as a capital recipient country. Meanwhile, the home state is the country from which the foreign investor originates or is referred to as the country that owns capital. The relationship between the host state and the home state is formed along with the implementation of foreign investment by the parties from each country, which involves the motives and interests of each party. For the host state, the interest they pursue is the existence of capital that can move the wheels of the country's economy, while on the one hand using their power to regulate foreign investment activities, to minimize the impact that may be detrimental to the country. On the other hand, the home state pursues profits from its investments in the host state, while ensuring that there is adequate and guaranteed protection for its citizens who become investors in the host state.

The international communities are aware that a balance is needed between the interests of the host state and the home state. In this case, there is an assumption that the World Trade Organization ("WTO") needs to take part in regulating the implementation of foreign investment. Therefore, a discussion about that awareness was raised in the Working Group on the Relationship between Trade and Investment in 2002, which essentially stated that:

"any framework should reflect in a balanced manner the interests of home and host countries, and take due account of the development policies and objectives of host governments as well as their right to regulate in the public interest" (Subaedi, 2008).

However, in its development, this matter was not followed up further because, in the end, the WTO decided to set aside discussions related to foreign investment law. Even though it was not appointed by the WTO, the concern that emerged in the working group has shown the importance of efforts to achieve a balance between the interests of the host state and the home state in the implementation of foreign investment.

The term "Right to Regulate," is a well-known term in the implementation of foreign investment. The Right to Regulate is one of the basics possessed by the host state in the practice of foreign investment, which essentially means that the host state has rights based on international law or investment treaties, in establishing rules and policies at the national level. In investment treaties, the definition of the Right to Regulate is usually stated in several doctrines or legal principles of foreign investment, such as indirect expropriation, fair and equitable treatment, and national treatment standards (Trujillo, 2018). These rights cannot only be exercised infinitely but must comply with several applicable provisions, one of which remains under international commitments. However, in certain circumstances, the state government in this case the host state may take certain steps in regulating matters relating to foreign investment if it is in an emergency.

Regulation in the practice of foreign investment is considered a right to regulate owned by the host state because foreign investment is a form of activity carried out within the territorial boundaries of a country (Soernarajah, 2010). Because it is run in the territory of the host state, the host state has the right and authority to regulate the course of these activities. The rights and authorities possessed by the host state arise from the concept of state sovereignty, which is inherent in each country in carrying out a relationship with other countries.

Based on the 1949 Draft Declaration on Rights and Duties of States, which was drawn up by the International Law Commission, sovereignty is recognized as one of the basic rights owned by the state. Furthermore, based on the Declaration on Principles of International Law Friendly Relations and Co-operation Among States in Accordance with the Charter of the United Nations 1970, each country has equal sovereignty, so that each country also has equal rights and duties.

One form of sovereignty possessed by the state is economic sovereignty. Economic sovereignty appears as a form of power possessed by a country within its territory, to regulate and implement regulations in its economic field (Herdegen, 2016). Economic sovereignty as a right owned by each country is regulated in Article 2 (1) of The Charter of Economic Rights and Duties of States 1974, which stated:

"Every State has and shall freely exercise full permanent sovereignty, including possession, use and disposal, over all its wealth, natural resources and economic activities."

Economic sovereignty is divided into 2 (two) types, which are: internal sovereignty, and external sovereignty. In short, internal sovereignty is the power of the state to regulate internally, namely all matters relating to economic activities in its country, either personal (regarding its citizens), territorial (regarding the territory and the resources in it), or functional (sovereignty which is limited to certain areas, for example, exclusive economic zones) (Adolf, 2005; Qureshi, 1999). In contrast to internal sovereignty, external sovereignty is a form of state power to interact in international relations with other countries in the economic field. Through 
internal sovereignty, every country that enters the territory of a country will be subject to all the rules contained in the country where it enters. Meanwhile, with external sovereignty, a country will be subject to the rules of other countries that interact with it, if there is an agreement between the two or more countries to use the rules of one of the countries as a legal basis in the transactions they carry out. In the implementation of foreign investment, the recognition of economic sovereignty is important, which underlies the embodiment of the host state's Right to Regulate, in the implementation of foreign investment in their territory. The Right to Regulate is a manifestation of the state's internal sovereignty in foreign investment activities.

One of the rules that are usually used as a basis in implementing foreign investment in the aviation industry, especially in airlines, is the Nationality Rule. The Nationality Rule is based on the nationalities of the parties in foreign investment. In foreign investment in the aviation industry, the nationality rule is applied by directing the nationality of the host state and restricts the movement of an airline in seeking investors, selling its equity shares, or merging with other airlines (World Economic Forum, 2016). These limitations arise because with the Nationality Rule, activities of an airline are usually controlled or majority-owned by a party with nationality as the country of origin of the airline, thus, foreign investors have such small possibility to enter and be involved in conducting business with the airline.

The implementation of foreign direct investment (FDI) is very vulnerable to commercial risk and noncommercial risk. Commercial risk is the risk that arises from investment activities as a result of the combination of operational, business, and financial risks. Meanwhile, the non-commercial risk is identical to the risk arising from political and socio-cultural problems that occur in a country, either in the form of country risk, namely political risks arising from government or social structures; and natural risk, namely risks that arise from nature, such as natural disasters (e.g., floods, earthquakes, etc.), as well as from humanitarian disasters (e.g., famine) (Kasatuka \& Minnitt, 2006).

In investment in the form of an aircraft lease, risk can also arise from the aircraft as the main asset in the lease agreement between the lessor and the lessee. There are 2 (two) main forms of risk in the implementation of aircraft leases, which are: asset risk, and credit risk. Asset risk is very important to be considered in the implementation of aircraft leases, given that if the investment value decreases, most of the potential profits will be lost, so it is necessary to ensure that the assets in the investment, which is aircraft that are leased, have great potential to return the investment value (Ackert, 2012). Credit risk, also known as performance risk, is a risk that arises due to an opportunity where one of the parties to the contract does not fulfill the agreed obligations, causing losses to the other party (Brown \& Moles, 2014). In aircraft leasing, the risk in the implementation of foreign investment is a very important thing for investors to pay attention to because the possibility of FDI facing these risks is greater when compared to foreign portfolio investment (FPI) since FDI is carried out directly in the host state.

Given the risks involved in the implementation of foreign investment, foreign investors need guarantees that their investment activities in the host state can run safely and smoothly so that foreign investors are less likely to suffer losses. The guarantee is usually in the form of protection against the implementation of foreign investment ("Investment Protection") which is realized through international rules, as well as internationally recognized and applicable principles. The standard of investment protection is intended to protect the interests of foreign investors from host state actions that may harm the interests of foreign investors (UNCTAD, 1999b). One of the main protections needed by foreign investors is protection against possible expropriations, nationalization, and other things that violate the ownership rights of foreign investors by the host state. Therefore, the standard of investment protection is applied and recognized internationally by business countries (Pratama \& Amalia, 2020), so that protection in the implementation of foreign investment can be actualized.

In this regard, even though the host state also has an interest in implementing foreign investment in its country, the host state must still guarantee and ensure that the rights owned by foreign investors are regulated and clearly stated in the applicable legislation and regulations, so that these rights truly recognized by the parties in foreign investment activities, and protected by the host state

\subsection{Regulation on Aircraft Lease as a Form of Foreign Investment}

Internationally, the implementation of aircraft lease does not yet have its own legal framework that is recognized and used by countries that implementing the aircraft lease practices. Due to its private nature, which is an agreement between the lessee and the lessor, the rules in the implementation of an aircraft lease are usually based on the leasing agreement agreed by the parties. Although there is no uniform law for the implementation of aircraft leases, the approval of the Convention on International Interests in Mobile Equipment (commonly called the Cape Town Convention ("CTC")) in 2001 was enough to create a breath of fresh air for the practice of aircraft leases, because CTC is intended to protect the interests of parties involved in financial practices related to aviation assets, by trying to minimize the risks that may arise from the sale or lease of aviation assets.

As a country that has ratified the CTC, and the Protocol on Specific Matters to Aircraft Equipment ("Aircraft Protocol"), Indonesia enforces one of the protection instruments adopted from the CTC, namely 
Irrevocable Deregistration and Export Request Authorization ("IDERA"). IDERA is an instrument that is included in the Protocol on Specific to Aircraft Equipment, in the form of a request for deregistration and aircraft export, which is intended to protect the aircraft owner if the lessee is in default in the aircraft leasing agreement (Masyarakat Hukum Udara, 2019). Indonesia ratified the CTC and the Aircraft Protocol through Presidential Regulation Number 8 of 2007. Through the Presidential Regulation, Indonesia adopted the provisions contained in the conventions and protocols, while affirming several provisions in them.

In Indonesia, aircraft lease is a practice that is mostly carried out by national airlines in the context of providing their aircraft fleet. As discussed in the Introduction section, the aircraft used by national airlines (including Garuda Indonesia Group and Lion Air Group), are mostly aircraft leased from foreign lessors. Aircraft to be operated by Indonesian airlines must be registered with the Directorate General of Civil Aviation, provided that the aircraft is not registered in another country; the age of the aircraft is under the age limit stipulated for the aircraft of that type; and, if the aircraft is a leased aircraft, it is required that the lease term of the aircraft is at least two years.

Aircraft lease agreements in Indonesia are regulated in national law through Article 71 of Law Number 1 of 2009 on the Aviation ("Aviation Law"). The aircraft lease agreement in the Aviation Law is stated using the term "leasing agreement." In the article, it is stated that there is an international interest in the aircraft used as the object of flight through the aircraft leasing agreement. This article implies that because the implementation of aircraft leasing is usually related to foreign parties, there is an interest from the relationship that occurs as a result of the aircraft lease agreement, which consists of the national interest of the host state, as well as the international interest of the relationship between the host state (the country of the national airline) with the home state (the country of the lessor/leasing company).

Guidelines regarding lease agreements in Indonesian law are regulated by the Ministry of Transportation in the Regulation of the Director General of Civil Aviation Number KP 126 of 2016 on the Operational Technical Guidelines Section 8900 -3.13 (Advisory Circular 8900 -3.13) Leasing Agreement. This guideline is intended for national airlines so that they have guidelines regarding the aircraft leasing agreement process, in which there is an attachment regarding the basic things that need to be known if they want to enter into an aircraft leasing agreement.

In the Aviation Law, the regulation regarding the commercial activities of the aviation industry is actualized by including provisions regarding commercial air transportation. Article 1 Number 14 of the Aviation Law defines commercial air transportation as air transportation that can be used by the public by collecting payments. Furthermore, in Article 108 of the Law, it is stated that commercial air transportation activities are carried out by business entities engaged in national commercial air transportation, whose entire or most of the capital is owned by Indonesian legal entities or Indonesian citizens. Capital ownership by national legal entities or Indonesian citizens is a must. If the capital is divided into several ownerships, then the capital ownership of one national capital owner must remain greater than the total capital ownership of the foreign capital owner (single majority). The provisions of Article 108 indicate that foreign capital owners have a very limited capacity to provide their capital in a national commercial air transportation business entity, by ensuring that the capital provided by one national capital owner must remain greater than the amount of capital provided by all capital from the foreign owners in the business entity. Article 108 can be considered as one of the embodiments of the nationality rule because in this case, the article stipulates that it is Indonesian citizens or legal entities who are allowed to take greater control than the foreign parties who are trying to enter the airline's business so that foreign parties have a very limited space to engage in the industry.

Meanwhile, investment activities in Indonesia are regulated by Law Number 25 of 2007 on the Investments ("Investment Law"), which defines foreign investment as:

"activities to invest by foreign investors, by fully using foreign capital, as well as jointly with domestic investors, to conduct business in the territory of the Republic of Indonesia."

We can see that the intended foreign investment mentioned in the article above is in the form of foreign direct investment ("FDI"), which is a form of transfer of assets from one country to another, where the invested capitals/assets are realized through physical presence, namely by establishing a company in another country, and cannot be withdrawn or transferred at any time (Soernarajah, 2010). The rights of foreign investors in the implementation of investment in Indonesia are protected as written in Article 14 Letter " $a$ " of the Investment Law which essentially states that all investment actors, both domestic investors, and foreign investors are entitled to protection, as well as rights and legal certainty.

Based on Presidential Regulation Number 44 of 2016, there are several business fields of the aviation industry that are open to foreign investment. Of these business fields, 4 (four) of them are allowed to do foreign investments of 67\%, namely: (a) Air Transport Support Services (including aircraft leases); (b) Airport Related Services; (c) Aircraft Freight Expedition Services; (d) General Sales Agent of Foreign Air Transport Company. Meanwhile, airport services are a line of business for the aviation industry that is allowed to make foreign investments of a maximum of $49 \%$. Non-Commercial Air Mode Transportation, as well as Commercial Air 
Transportations, whether scheduled domestically, scheduled overseas, or unscheduled, are also available for foreign investment of $49 \%$, but with the same provisions in the Aviation Law as previously discussed, which stated that capital from national capital owners must remain greater than the total capital provided by foreign investors (single majority). Reflecting on the Government Regulation Number 44 of 2016, aircraft leasing is one of the fields open to foreign investors to invest $67 \%$ of the time. That is why many foreign companies are interested in becoming lessors in Indonesia's national airlines.

Arrangements regarding aircraft leases in Indonesia can also be seen through the Regulation of the Minister of Transportation Number PM 97 of 2015 on the Guidelines for the Implementation of Aircraft Ownership and Control. In this regulation, the Government stipulates rules regarding the minimum number of aircraft owned by airlines. Every airline that is a holder of a commercial air transportation business license is not only required to own a certain number of aircraft but also controls a certain number of aircraft. This Regulation stated that there are several options in terms of controlling the aircraft through aircraft leasing, as referred to in Article 4 Paragraph (2), namely from foreign lessors, or domestic lessors; in the form of dry leases or wet leases, where it is required that the leased aircraft must be included in the operation specification of the airline that rents it. This was further regulated recently in Article 27 Paragraph (2) of Government Regulation Number 32 of 2021 on the Implementation of the Aviation Sector. Both PM 97 of 2015 and Government Regulation No. 32 of 2021 also explain that aircraft leasing can be a way for airlines to own aircraft if the aircraft leasing has the option to purchase (lease to be purchased).

\section{Urgency of a Legal Protection for the Implementation of Aircraft Lease During Covid-19 Pandemic}

\subsection{Implementation of the Aircraft Lease in Indonesia during the Covid-19 Pandemic}

In the practice of aircraft leasing carried out by Indonesian airlines, aircraft leased by an airline do not only come from one lease company but several different lease companies. The companies that become lessors ("leasing companies") are usually foreign companies, which also come from different countries. For example, Garuda Indonesia is known to lease its aircraft from a total of 31 leasing companies. Four of the 31 leasing companies are, AerCap (Ireland); Helice Leasing S.A.S (France); Nordic Aviation Capital (Denmark); and Export Development Canada (Canada). Meanwhile, Lion Air also leases lots of its aircraft from foreign leasing companies, including leasing companies from Ireland, Singapore, and the United States. Some of the leasing companies that lease their aircraft to Lion Air are as follows:

\begin{tabular}{|cc|}
\hline Lessor (as manager) & Number of aircraft \\
\hline Avolon & 22 \\
\hline BOC Aviation & 17 \\
\hline SMBC Aviation Capital & 15 \\
GECAS & 14 \\
Goshawk & 13 \\
Aircastle & 12 \\
\hline Aviation Capital Group & 11 \\
\hline Falko & 10 \\
\hline BBAM & 8 \\
\hline Airborne Capital & 8 \\
\hline
\end{tabular}

Figure 2. Lion Air Lessors

Source: Cirium Fleets Data (Cirium, 2021)

The relationship between each leasing company as the lessor and the airline as the lessee is carried out based on the agreement contained in the provisions of the lease agreement between the two parties. Each lease agreement may have specific terms that are different from other lease agreements. For example, the provisions regarding the aircraft leasing period stipulated in the lease agreement between Lion Air (as the lessee) and Avolon (as the lessor) will be different from the provisions in the lease agreement between Lion Air (as the lessee) and Goshawk (as the lessor), because the agreement made in both lease agreements vary depending on the agreement of both parties. Even though they have different agreements, basically every lessor must be treated equally according to the agreement between them and the airline as the lessee.

In the implementation of foreign investment, an investment agreement can be renegotiated if, in the course of it, certain conditions greatly disrupt the stability of the agreement implementation. Renegotiation contained in an investment agreement usually does not lead to the interests of legal stability but is more focused on interests in the economic field (Rudolf Dolzer \& Schreuer, 2012). As a form of investment, the aircraft lease agreement can also be renegotiated between the lessee and the lessor if there is an unavoidable change in the situation during the lease term. Currently, two major Indonesian airlines, Garuda Indonesia, and Lion Air are in the stage of renegotiation with their respective lessors to discuss the continuation of their aircraft leasing contract.

Renegotiations between Garuda Indonesia and each of its lessors are currently being carried out by asking the lessor to provide a discount on the aircraft rental fee. This application was made on the basis that the pandemic conditions had caused airplanes as a mode of transportation to temporarily cannot operate normally 
and caused a drastic decrease in the number of passengers compared to previous years so that Garuda Indonesia suffered losses in terms of income. As a result, Garuda Indonesia is unable to make payments for operational costs, including in terms of leasing costs payment. The renegotiations that are being carried out by Garuda Indonesia with each of its lessors are based on a business-to-business relationship, which is aimed at making benefits for both parties from the relationship they are running (Ramalan, 2021).

Just like Garuda Indonesia, Lion Air also renegotiates with its lessors to find any solutions that can be taken to be able to continue fulfilling their obligations in the leasing agreement, and especially about the reduction of lease payments. Lion Air said that they, as the lessee, treat all lessors equally in every renegotiation, no one gets special treatment (Puspa, 2020). Several payment reliefs schemes that have been proposed by Lion Air to its lessors are as follow:

a. Power-by-the-hour Payments

Power-by-the-hour payments are calculated based on the length of time an aircraft is being used. In this case, the airline as the lessee still has the obligations for the maintenance, storage, and use of the aircraft, but the payment he needs to make is only calculated based on the length of time the aircraft is operated (Hanley, 2012), thus, if the aircraft is not being used or being grounded, the cost of the aircraft is not calculated as a part that needs to be paid.

b. Gradual Payment over the next 18 months

Leasing payments under this scheme will be divided into 5 (five) terms, consist of:

1) Payment of $10 \%$, made between September and November 2020 ;

2) Payment of $20 \%$, made between December 2020 and May 2021;

3) Payment of $25 \%$, made between June and August 2021;

4) $50 \%$ payment, made between September and November 2021 ;

5) Payment of $80 \%$, made between December 2021 and February 2022. (Cirium, 2020)

Of the two schemes proposed by the Lion Air Group, lessors are said to be more in favor of the second scheme, which is the gradual payment scheme, because it is considered more profitable for lessors than the power-by-the-hour payments.

A bad possibility that may be faced by the Indonesian airlines is if the renegotiations are not well received by the lessor, the lessor may file a legal action against the airlines' obligation to pay the lease costs, which for now has not been able to be fulfilled by the airline. The Indonesia National Air Carriers Association (INACA), which is consists of national airlines, expressed their hope that the government could provide support for scheduled airlines against the possibility of legal action proposed by the lessors. In addition, INACA also proposes that the government provide relaxation to the regulations that are currently being a burden for the aviation industry, especially in terms of the aircraft lease activities.

\subsection{Government Efforts for the Implementation of Aircraft Leasing Amid Covid-19 Pandemic}

During the Covid-19 pandemic in Indonesia, the Government has issued several regulations aimed at reducing the risk of the spread of Covid-19 in Indonesian territory. The emergence of these regulations directly or indirectly affects the implementation of Indonesian aviation activities, both domestic and international. On April 13, 2020, about a month after the release of a statement from the World Health Organization (WHO) which gave the status of the Covid-19 pandemic as a Global Pandemic, the Government of Indonesia declared Covid-19, which is a non-natural disaster, as a National disaster through the Presidential Decree Number 12 of 2020.

A few weeks before the enactment of Presidential Decree No. 12 of 2020, the Minister of Law and Human Rights of the Republic of Indonesia has issued the Regulation of Minister of Law and Human Rights Number 11 of 2020 on the Temporary Prohibition of Foreigners from Entering the Territory of the Republic of Indonesia ("Permenkumham 11/2020"). The Permenkumham was later revoked in September 2020, through the enactment of the Regulation of Minister of Law and Human Rights Number 26 of 2020 on the Visas and Stay Permits in the New Customs Adaptation Period ("Permenkumham 26/2020"). Both Permenkumhams are essentially trying to reduce the number of foreigners entering Indonesian territory during the Covid-19 pandemic so that the risk of transmission of the virus in Indonesia does not increase. Permenkumham also affects the aviation world because it limits the movement of people outside Indonesia to fly into Indonesian territory so that the number of airplane passengers decreases compared to the usual number and causes many flight schedules to be reduced.

In addition to the issuance of the Permenkumham which affects flight activities, the issuance of the Regulation of Minister of Transportation ("Permenhub"), also affects the intensity of Indonesia's aviation activities. As the party that directly regulates the implementation of various modes of transportation in Indonesia, the Minister of Transportation has issued the Permenhub several times, which contains regulations for aircraft passenger capacity, as well as health protocols that must be carried out in-flight, including filling out health alert cards; implementation of physical distancing; coordination with the Covid-19 crisis center, etc. The Permenhubs are intended to limit and control transportation modes during the pandemic, as an effort to suppress the spread of Covid-19. In addition to regulations, the Minister of Transportation has also issued several Circulars, which 
contain instructions for air transportation activities, both domestic travel, and international travel, during the Covid-19 pandemic.

Through the Permenhub PM 18 of 2020 initially, aircraft passengers were limited to a maximum of $50 \%$ of the total aircraft seating capacity. However, in Permenhub PM 41 of 2020, this provision was changed, which made the number of passengers who were limited from the number of aircraft seating capacities would later be determined by the Minister, so that in the Regulation there was no mention of the specific size of the number of passengers in an aircraft. The regulation about this matter also changed through the Circulars of the Ministry of Transportation Number 13 of 2020 ("SE 13/2020") which has been relaxing the maximum capacity of aircraft passengers to $70 \%$, but this rule was later changed again through the Circulars of the Ministry of Transportation Number 3 of 2021 ("SE 3/2021"), which removes the use of the maximum number of passengers of $70 \%$ on the aircraft. Through the new rules from SE 3/2021, airlines are allowed to decide the maximum capacity for each flight, but of course not up to $100 \%$. In addition, airlines are also asked to vacate three rows of seats on each flight, as a place of quarantine for passengers who have the Covid-19 symptoms. The load factor rules according to the SE 3/2021 was continuing to be applied to subsequent Circulars (SE 10/2021, SE 19/2021, SE 26/2021, SE 34/2021, SE 38/2021), until finally replaced through Circulars of the Ministry of Transportation Number 45 of 2021 ("SE 45/2021"), which re-enact the regulation on the number of passengers from the SE 13 of 2020 , which regulates that the maximum number of passengers is $70 \%$ of the aircraft load factor.

The Indonesian Government has not issued any regulation that specifically regulates foreign investment activities during this Covid-19 pandemic situation. However, there are several policies in the economic sector issued by the Government in the effort to maintain Indonesia's economic stability. The first one is the Government Regulations in Lieu of Legislation Number 1 of 2020 ("Perppu 1/2020"), which has been enacted into law through Law Number 2 of 2020. It regulates the implementation of the national economic recovery program, which is intended by the Government to protect the economic capacity of business actors, through assistance in the form of state equity participation, placement of the Government funds or investments, as well as guarantees following the scheme determined by the Government.

Assistance in the context of national economic recovery for companies is regulated by the Minister of Finance through Regulation of the Minister of Finance Number 118/PMK.06/2020. Assistance from the Government to companies is carried out to State-Owned Enterprises ("SOEs") in two forms, i.e., investment in the form of debt securities issued by SOEs as the recipient of the investment, and direct investment in the form of providing loans to SOEs. For SOEs in the aviation sector, the provision of loans from the Government in this national economic recovery program is done by the Mandatory Convertible Bond (MCB) scheme or the issuance of debt securities.

During this pandemic period, the Governments of each country are trying to revive their aviation industry through the provision of financial assistance. Many countries have provided financial assistance directed to their national airlines, which are hardly affected by the COVID-19 pandemic. Some of the financial assistances are:

Table 2. Government Aid for Airlines

\begin{tabular}{|c|c|}
\hline Country & Forms of the Aid for Airlines \\
\hline Singapore & $\begin{array}{l}\text { The Singaporean Government announced a comprehensive assistance package of US\$80 } \\
\text { million, for the aviation industry. }\end{array}$ \\
\hline Thailand & $\begin{array}{l}\text { A total of } 8 \text { (eight) airlines registered in Thailand will get a soft loan from the Ministry of } \\
\text { Finance, with a total of THB } 24.15 \text { billion, and interest of } 2 \% \text { for five years. }\end{array}$ \\
\hline \multirow[t]{2}{*}{ China } & $\begin{array}{l}\text { People's Republic of China (PRC): } \\
\text { - The PRC proposed a package of assistance known as the " } 16+8 \text { " policy, which consists of } \\
16 \text { (sixteen) actions and } 8 \text { (eight) policies, all of which are intended as an aid to airlines } \\
\text { during the COVID-19 pandemic. } \\
\text { - According to information from the Civil Aviation Administration of China in July 2020, } \\
\text { airlines have received financial assistance worth RMB10 billion. }\end{array}$ \\
\hline & $\begin{array}{l}\text { PRC, Hong Kong, Macao, Taiwan: } \\
\text { In October } 2020 \text {, local airlines announced that they would receive US } \$ 4.6 \text { billion or CNY } 31 \\
\text { billion investment from state-owned investors. }\end{array}$ \\
\hline \multirow[t]{3}{*}{$\begin{array}{c}\text { Republic of } \\
\text { Korea }\end{array}$} & $\begin{array}{l}\text { Following the Government-guaranteed bond plan of KRW } 1 \text { trillion, airlines based in the } \\
\text { Republic of Korea will be provided with financing by the Korean Development Bank of KRW } \\
800 \text { billion. }\end{array}$ \\
\hline & $\begin{array}{l}\text { The local government of Jeju Island has allocated KRW } 4 \text { billion to buy shares of local } \\
\text { airlines. }\end{array}$ \\
\hline & $\begin{array}{l}\text { The local government of Gangwon-do is currently allocating KRW } 3 \text { billion, which is aimed at } \\
\text { supporting the activities of local airlines. }\end{array}$ \\
\hline
\end{tabular}




\begin{tabular}{|c|c|}
\hline & $\begin{array}{l}\text { The Government will provide financial assistance in the form of capital injections to two } \\
\text { airlines based in the Republic of Korea through the Main Industry Stabilization Fund program. } \\
\text { The distribution of the capital injections are as follows: } \\
\text { - Airline 1: KRW } 2.4 \text { trillion; } \\
\text { - Airline 2: KRW } 190 \text { billion. }\end{array}$ \\
\hline \multirow[t]{2}{*}{ Australia } & $\begin{array}{l}\text { The Australian Federal Government assisted the aviation industry with a US\$940 million total } \\
\text { amount, as well as additional commitments of US } \$ 228 \text { million. }\end{array}$ \\
\hline & $\begin{array}{l}\text { The Queensland State Government will provide investment and debt loans of US\$143 million } \\
\text { to local airlines on the condition that the airline must remain headquartered in the Queensland } \\
\text { region for the next } 10 \text { years. }\end{array}$ \\
\hline New Zealand & $\begin{array}{l}\text { The government has announced that it will open a US\$524 million loan facility for local } \\
\text { airlines. }\end{array}$ \\
\hline Russia & $\begin{array}{l}\text { The Russian Government will provide an emergency fund with a total of US\$130 million to } \\
\text { Russian airlines, which is aimed at improving financial conditions, aircraft leases payment, } \\
\text { salaries payments, and other emergency expenses. }\end{array}$ \\
\hline France & $\begin{array}{l}\text { The Government will provide financial aids of a total of EUR } 7 \text { billion, for its national airlines, } \\
\text { consisting of a dependent loan of EUR } 4 \text { billion, and direct loans of EUR } 3 \text { billion. }\end{array}$ \\
\hline
\end{tabular}

Source: International Air Transport Association (International Air Transport Association, 2021)

These financial aids can later be used for airline financing purposes, including the payment of aircraft lease costs. In Indonesia itself, the Government has launched a number of stimuli that can help to ease the burden on the aviation industry. Funds intended as a stimulus for the aviation industry are Rp443 billion in 2020, and Rp1.48 trillion in 2021 (Biro Komunikasi Informasi Publik, 2020). For the aviation sector in general, the government has prepared assistance in the form of subsidies for Aircraft Passenger Services ("PJP2U") (Kementerian Koordinator Bidang Perekonomian Republik Indonesia, 2021). The Government's subsidy for the PJP2U has been materialized in October 2020. The government has waived the PJ2PU tariff for 23 October - 31 December 2020 at 13 Indonesian airports, to increase demand for flight activities. This subsidy caused plane tickets to be cheaper, as an effort to attract people to start travel again using air transportation. The Ministry of Transportation of the Republic of Indonesia stated that from his observations, during the implementation of this subsidy, aviation activities experienced an increase in performance by $60 \%$.

Furthermore, the Indonesian Government has also planned to provide tax incentives to business actors in the aviation industry as taxpayers. This tax incentive is regulated based on the Regulation of Minister of Finance Number PMK 9/PMK.03/2021, where incentives are applied to Article 21 Income Tax, Article 22 Import Income Tax, Income Tax Instalments, and Value-Added Tax (VAT) Restitution (Kementerian Koordinator Bidang Perekonomian Republik Indonesia, 2021). However, until April 2021, airlines as part of taxpayers in the aviation sector are still waiting for the realization of this tax incentive.

The Government aid in the form of funds from the National Economic Recovery Program ("PEN Program") in the aviation sector, was obtained by a state-owned airline, Garuda Indonesia (GIAA). In 2020, it was reported that Garuda Indonesia would receive an investment of Rp8.5 trillion from the Government as working capital for the airline. In December 2020, Garuda Indonesia issued an initial stage of MCB of Rp1 trillion with a tenor of 3 years. These funds have been issued by the Government since early February 2021. The issuance of the initial phase of funds of Rp1 trillion with a tenor of 3 years is based on the results of discussions with related parties, including the Ministry of State-Owned Enterprises, and the Ministry of Finance and Multi-Infrastructure Facilities, by considering the renegotiation efforts towards the aircraft lease costs, which carried out by Garuda Indonesia. The renegotiations on the aircraft lease costs are carried out for the entire fleets of Garuda Indonesia Group, including the aircraft used by Citilink airline, by asking the lessor to provide relief in the form of extension of the lease period, postponement of lease payments, and a decrease in the monthly lease cost.

In this regard, state-owned national airlines and private national airlines experience different treatment in the matter of assistance or aid received from the Government during the pandemic. Because PEN Program funds are only intended for SOEs, Lion Air as an example of a private airline does not receive financial assistance directly from the Government, unlike Garuda Indonesia which receives additional assistance in the form of a bailout fund as an investment by the Government through the PEN Program. Even though the conditions being experienced by Lion Air, Garuda Indonesia, and other national airlines are similar due to this pandemic situation, the funds obtained by Lion Air and other national airlines are purely from the implementation of the airline's business without any assistance from the Government, except in the case of the PJP2U subsidies. Furthermore, the Government's investment for Garuda Indonesia as an SOE, through the PEN program has previously been considered by looking at the results of the aircraft lease renegotiation which is used as a parameter for the Government to calculate the amount of the bailout fund to be provided. Meanwhile, Lion Air as a private airline does not receive such assistance from the Government, although it is also conducting renegotiations with the lessor for the continuance of their aircraft lease activity. 
The relationship that occurs in the lease agreement is only between the lessee and the lessor. However, based on Indonesian regulations, precisely in Article 25 of the Aviation Law, since aircraft that are operated by Indonesian airlines must be registered in Indonesia and may not be registered in other countries, aircraft leased by Indonesian airlines from foreign lessors must also be registered in Indonesia. In implementing FDI, Indonesia as the host state has the authority to regulate matters relating to the country's economic stability. These arrangements often affect FDI activities that are being carried out in the territory of their country, including aircraft lease activities, so that these activities can be affected by regulations issued by the host state Government. Leased aircraft that have been registered in Indonesia will certainly be one of the cores of the aviation industry which will be greatly affected if the Indonesian Government issues a regulation related to aviation.

All forms of regulations issued by the Government of Indonesia during the Covid-19 pandemic are a form of the right to regulate owned by Indonesia to ensure that the implementation of any activities, especially in the economic field during this pandemic situation, can still be carried out smoothly, the business agencies remain alive, and the relations with foreign parties in the legal and economic fields under the agreement can still run well. Although the economic interests are very important to be kept, considerations of health are the main focus that needs to be maintained in terms of the right to regulate by the host state during this pandemic situation.

In the practice of aircraft leases in Indonesian airlines, almost all of the investors (lessors) are foreign leasing companies from different countries. With this pandemic, it is very likely that not all foreign leasing companies that cooperate with national airlines will get the fulfillment of their rights because the airlines themselves are experiencing financial difficulties, so there may be an imbalance, between a leasing company who has received the fulfillment of its rights, although not completely; and other leasing companies who have not yet had their rights fulfilled, even though they are all lessors of the same airline (lessee).

Broadly, questions may arise about the actions that the lessee's state as the host state can take to ensure the operation of the aircraft lease, especially to all foreign lessors. In this case, the application of the most favored nation standard is an important basis for ensuring equal treatment from the host state to lessors from different countries. Most Favored Nation treatment ("MFN") is defined in the Draft Articles on Most Favored Nation Clauses (1978) as:

"treatment accorded by the granting State to the beneficiary State, or to persons or things in determined relationship with that State, not less favourable than treatment extended by the granting State to a third State or to persons or things in the same relationship with that third State."

The MFN principle arises intending to realize the competitive equality between countries that carry out foreign investment activities in a host state and is applied as a basis for foreign investors from these countries to receive the same treatment as foreign investors from other countries, who are equally doing investment on the same objects, in the host state region. This principle is the manifestation of the non-discrimination principle that departs from the principle of reciprocity in the implementation of foreign investment, which ensures that no foreign investor from a country receives special treatment in doing an investment in the host state (Subaedi, 2008). All investors, regardless of their country of origin, must be treated equally, no one is more privileged. Because it prioritizes equal treatment, the MFN principle is sometimes associated with fair and equitable treatment, which is also intended to provide equal and fair treatment for foreign investment actors.

Fair and Equitable Treatment is an international minimum standard. As the name implies, literally fair and equitable treatment ("FET") is defined as a form of fair and equal treatment for anyone who does international relations. Although several principles of protection in foreign investment (standards of investment protection), for example, national treatment standard, and MFN, are often associated with FET, the FET principle itself is part of the overall system contained in the standards of investment protection, so it considered as fundamental for the implementation of foreign investment (Klager, 2011).

Through the FET principle, the most basic level of protection for foreign investors, which is the value of justice and equality, is reflected (Subaedi, 2008). In Indonesia, FET is embodied through the principles that underlie the Investment Law, including the principle of equal treatment, the principle of legal certainty, and the principle of transparency (Putri et al., 2018). The FET principle is a milestone for the principles of nondiscrimination that are used as protection in foreign investment, to ensure that investment practices, especially those that are cross-border, are carried out without any discrimination by the host state so that every investor from any country has the opportunity and treated equally by the host state. The status of MFN as a principle of non-discrimination is what causes MFN to be often associated with FET. In the connection between the two principles, FET is an absolute principle, not dependent on other principles, while MFN is a principle that wants to encourage the realization of FET in foreign investment (UNCTAD, 1999a). Thus, if FET seeks to ensure equality and justice for investors as the minimum form of protection in foreign investment, MFN embodying it by affirming the implementation of non-discriminatory behavior towards each state that carries out foreign investment.

Based on the MFN principle, the Indonesian government must treat lessors as investors in the implementation of aircraft leases equally. If this equal treatment is intended for all lessors who lease their aircraft 
to Indonesian national airlines, with the MFN principle, all those lessors will be treated the same without any distinction by the host state. For example, AerCap as the lessor of Garuda Indonesia, and GECAS as the lessor of Lion Air, will still be treated the same by the Government of Indonesia because both are foreign investors investing in Indonesian companies. Although the status of the two airlines is different, where Garuda Indonesia is a state-owned airline, and Lion Air is a private airline, the treatment from the state that is received by investors, in this case, the lessor should not be distinguished.

As the Covid-19 pandemic situation has made it difficult for national airlines to fulfill their obligations to the lessor, Indonesia as the host state has a duty to ensure that external parties, which in this case are the lessors, will continue to obtain the fulfilment of their rights under the agreement that has been agreed with the national airline, as the lessee. On the other hand, considering the position of airlines that are in a slump due to this pandemic, national airlines also need to be assisted by the state, to be able to fulfil their obligations to the external parties.

Equal treatment of lessors during this pandemic will be difficult to achieve if the financial assistance provided by the government is only aimed at airlines with certain conditions, for example, as is happening in Indonesia now, the assistance is only intended for state-owned airlines, while private airlines do not receive such financial assistance. This affects the airline's ability to gradually fulfill its obligations to the second party. With the assistance of funds provided by the government, state-owned airlines at least have the option to make small payments to lessors following the results of the renegotiations with the lessee, although it is most likely that payments to lessors will not be immediately actualized because airline operational costs are not only regarding the aircraft leases. The Government assistance to the state-owned airlines will be quite profitable for them to ease the burden on the current condition of airlines, compared to private airlines that only rely on market conditions.

It will be an advantage for Garuda Indonesia's lessors if the financial assistance provided by the Government through the PEN Program is allocated by the airline for the payment of their aircraft lease costs. However, if this happens, there may be questions from the lessors of Lion Air or other private national airlines regarding the treatment they should also receive like lessors of Garuda, which is the airline's ability to fulfil their obligations as the lessee to pay the leases cost to the lessor

\section{Conclusion}

The right to regulate is one of the rights owned by the host state to regulate the course of foreign investment in its country, including in the event of an emergency. During the Covid-19 pandemic, the Indonesian Government has repeatedly used its right to regulate, to ensure that foreign business and investment can continue to run properly. Aside from all the regulations that have been issued by the Government in this pandemic situation, the Government has also issued financial assistance to state-owned airlines but there is still no financial assistance scheme aimed at private national airlines. Assistance provided by the government, both financial and nonfinancial, either directly or indirectly intended for the implementation of aircraft leases will not only help to ease the burden on airlines but also assist the lessor by at least providing certainty to the lessor regarding the current condition of the airlines and convince the lessor that the state is also trying to help its national airline to revive, so the airlines can fulfil all its obligations to the lessor.

In addition to the financial assistance, it is also necessary to think about the possibility of other forms of assistance that can be provided by the Government to national airlines as a whole, both state-owned and private. If it is indeed difficult to support airlines during this pandemic through financial assistance, then the Government may be able to think about easing the burden on airlines from the administrative side. For example, providing a written official statement that can be given by the national airline to the parties who were entered into an agreement with them, in which it states that the condition of the national airline is indeed not possible to fulfil its payment obligations as promised and that the state will continue to monitor and ensure that the airline will continue to fulfil its obligations to the second party so that the second party's rights are still fulfilled. In the aircraft lease agreement, this written official statement issued by the government may be used by the lessor as a guide or guarantee for the temporary suspension of the fulfillment of the lessee's obligations. Thus, in this case, the Government does not need to allocate funds, but rather assists by guaranteeing the activities of the national airline to the second party, including lessors, that cooperates with it, through a kind of official letter.

\section{References}

Ackert, S. (2012). Basics of Aircraft Market Analysis - Forming a Policy to Identify Ideal Assets for Long-term Economic Returns. In Aircraft Monitor.

Adolf, H. (2005). Hukum Ekonomi Internasional: Suatu Pengantar. PT Raja Grafindo Persada.

Biro Komunikasi Informasi Publik. (2020). Kemenhub Pastikan Pembangunan Infrastruktur Transportasi dan Pelayanan Berjalan Baik di 2021. http://dephub.go.id/post/read/kemenhub- pastikan-pembangunaninfrastruktur-transportasi-dan-pelayanan-berjalalan-baik-di-2021?language $=$ en 
Brown, K., \& Moles, P. (2014). Credit Risk Management. In Applied Econometrics (Vol. 13, Issue 1044). Edinburgh Business School.

Capital Aviation. (n.d.). Invest in the Capital Aviation Aircraft Investment Fund. Retrieved January 25, 2021, from http://www.capitalaviation.net/Aircraft-Investment

CH-Aviation. (2021). Indonesia's Lion Air Restructures Some Lease Deals - Report. https://www.chaviation.com/portal/news/100335-indonesias-lion-air-restructures-some-lease-deals-report

Cirium. (2020). Lion Air Tries New Approach with Lessors. https://www.flightglobal.com/ fleets/lion-air-triesnew-approach-with-lessors/140759.article

Cirium. (2021). Lion Reaches Agreements with (Some of) its Lessors. https://www.flightglobal.com/ strategy/lion-reaches-agreements-with-some-of-its-lessors/142258.article

Etfs, G. (2017). Investor's Guide to the Global Airline Industry.

Herdegen, M. (2016). Principles of International Economic Law. Oxford University Press.

International Air Transport Association. (2021). Aviation Relief Measures (Update) (Issue January).

Jia, X. (2020). Global Airline Outlook: Are Airlines Investable Post COVID-19? https://www.seahawkinvestments.com/2020/06/25/global-airline-outlook-are-airlines-investable-post-covid-19/?lang=en

Kasatuka, C., \& Minnitt, R. C. A. (2006). Investigation and non-commercial risks in developing countries. Journal of the Southern African Institute of Mining and Metallurgy, 106(12), 849-856.

Kementerian Koordinator Bidang Perekonomian Republik Indonesia. (2021). Stimulus Ekonomi untuk Sektor Aviasi Indonesia.

KGAL Real Investments. (2016). Aircraft leasing - A Promising Investment Market for Institutional Investors. $1-8$.

Klager, R. (2011). 'Fair and Equitable Treatment' in International Investment Law. Cambridge University Press. KPMG. (2021). The Aviation Industry Leaders Report 2021: Route to Recovery.

Law of the Republic of Indonesia Number 25 of 2007 on the Investment.

Law of the Republic of Indonesia Number 1 of 2009 on the Aviation.

Masyarakat Hukum Udara. (2019). Hak-hak Kreditur yang Dapat Didaftarkan di Indonesia Dalam Rangka Transaksi Pengadaan/Pembiayaan Pesawat Udara. http://masyarakathukumudara.or.id/hak -hak-kredituryang-dapat-di-daftarkan-di-indonesia-dalam-rangka-

transaksipengadaanpembiayaanpesawatudara/\#: :text=IDERA merupakan kuasa yang tidak,perjanjian sewa atau pembiayaan pesawat

Parama, M. (2020). Garuda Defers Fleet Renewal Amid COVID-19 Pressure on Finance. https://www.thejakartapost.com/news/2020/09/14/garuda-defers-fleet-renewal-amid-covid-19-pressure-onfinances.html

Pratama, P. R. P., \& Amalia, P. (2020). The ISDS Mechanism and Standards of Protection in the Investment Treaty. Lentera Hukum, 7(2), 137. https://doi.org/10.19184/ejlh.v7i2.17348

Puspa, A. W. (2020). Digugat Rp191,9 Miliar Soal Sewa Pesawat, ini Respons Lion Air. https://ekonomi.bisnis.com/read/20200924/98/1296125/digugat-rp1919-miliar-soal-sewa-pesawat-inirespons-lion-air

Putri, R. R., Chandrawulan, A.-A., \& Amalia, P. (2018). Peringkat Arus Investasi Indonesia Dalam Kerangka Asean-China Free Trade Agreement (Perbandingan Dengan Singapura, Malaysia, Thailand, Dan Vietnam) Ditinjau Dari Prinsip Fair and Equitable Treatment. Jurnal Hukum \& Pembangunan, 48(2), 275. https://doi.org/10.21143/jhp.vol48.no2.1664

Qureshi, A. (1999). International Economic Law. Sweet and Maxwell.

Ramalan, S. (2021). Tegas, Erick Thohir Minta Garuda dan Leasing Harus Saling Untung. https://economy.okezone.com/read/2021/02/10/320/2360067/tegas-erick-thohir-minta-garuda-dan-leasingharus-saling-untung?page $=1$

Rudolf Dolzer, \& Schreuer, C. (2012). Principles of International Investment Law. Oxford University Press. https://doi.org/10.1093/law/9780199651795.001.0001

Soernarajah, M. (2010). The International Law on Foreign Investment,. Cambridge University Press.

Subaedi, S. P. (2008). International Investment Law: Reconciling Policy and Principle. Hart Publishing.

The Insider Stories. (2020). Goshawk Aviation Sues Rusdi Kirana in London Court. https://theinsiderstories.com/goshawk-aviation-sues-rusdi-kirana-in-london-court/

Trujillo, E. (2018). Balancing Sustainability, the Right to Regulate, and the Need for Investor Protection: Lessons from the Trade Regime. Boston College Law Review, 59(18-63), 2735-2764.

UNCTAD. (1999a). Fair and Equitable Treatment.

UNCTAD. (1999b). Trends in International Investment Agreements: an Overview. In New York.

UNCTAD. (2020). Impact of the Coronavirus Outbreak on Global FDI (Issue March 2020).

Wareza, M. (2021). Ini Alasan Lengkap Garuda Kembalikan 12 Pesawat Bombardier. https://www.cnbcindonesia.com/market/20210210142321-17-222457/ini-alasan-lengkap-garuda- 
kembalikan-12-pesawat-bombardier

World Economic Forum. (2016). Industry Agenda A New Regulatory Model for Foreign Investment in Airlines (Issue January). www.weforum.org 